\title{
Management of sickle-cell disease
}

\author{
JOHN STUART \\ From the Department of Haematology, The Children's Hospital, Birmingham
}

The two most controversial aspects of the management of sickle-cell disease are first, the treatment of the painful, vasoocclusive crisis and second, the value of community screening programmes. The controversy over treatment of the painful crisis has followed the promotion of urea as a clinically effective anti-sickling agent (Nalbandian, Shultz, Lusher, Anderson, and Henry, 1971; McCurdy and Mahmood, 1971) against a long background history of failure to evaluate potential anti-sickling agents by controlled clinical trial. The controversy over community screening has been exacerbated by the passage, in 1972, of the United States Congress National Sickle Cell Anemia Control Act; as a result, 10 states, containing more than $40 \%$ of the black population of the USA, have introduced laws requiring mandatory, rather than voluntary, screening for sickle-cell haemoglobin (Rutkow and Lipton, 1974).

Both of these aspects are now relevant to the care of immigrant patients in the United Kingdom and to the establishment in this country of cooperative clinical trials and community screening programmes.

\section{Management of the Sickle-cell Crisis}

\section{TYPES OF CRISIS}

The term 'crisis' in sickle-cell disease may be used to describe the vasoocclusive episodes of tissue infarction (painful crisis) or episodes of sudden anaemia resulting from marrow hypoplasia, an exacerbation of haemolysis, or splenic sequestration (haematological crisis). In a paediatric population receiving folic acid supplements we have found that hyperhaemolytic crises and episodes of erythroid hypoplasia are relatively common causes of a profound fall in haemoglobin. These haemolytic episodes may be precipitated by a viral infection associated with cold antibody formation (Cotter, Walker, Bird, Mann, and Stuart, 1974). There is, however, insufficient information concerning the frequency and cause of these hypoplastic, haemolytic, and sequestration crises, and cooperative studies involving investigation and treatment are required. This is particularly important in obstet- rical practice because of the high maternal and perinatal mortality (Fort, Morrison, Berreras, Diggs, and Fish, 1971).

VASOOCCLUSIVE CRISES AND PRECIPITATING FACTORS

The painful, vasoocclusive crisis of sickle-cell anaemia is more common in children than in adults (Diggs, 1965), but occurs on average only 2.8 times per patient per year (table I). A cross-over study of prophylactic therapy will therefore require at least two years before any conclusion regarding a significant reduction in crisis frequency can be drawn.

\begin{tabular}{lll}
\hline $\begin{array}{l}\text { Age Group } \\
\text { (Years) }\end{array}$ & $\begin{array}{l}\text { Crises/Patient/ } \\
\text { Year }\end{array}$ & Reference \\
\hline $\begin{array}{ll}\text { Children and } \\
\text { adults }\end{array}$ & $2 \cdot 5$ & \\
$0.25-20$ & 3.9 & Oski, Call, and Lessen (1968) \\
$3.5-17$ & 2.6 & Diggs and Flowers (1971) \\
$5-21$ & 2.1 & Lubin and Oski (1973) \\
$5-17$ & 2.9 & Lusher and Barnhart (1973) \\
& mean $2 \cdot 8$ & Mann and Stuart (1974) \\
\end{tabular}

Table I Reported frequency of vasoocclusive crises in sickle-cell disease

Of the many factors which may precipitate a vasoocclusive crisis, infection is one of the most common and is an important cause of death, particularly in childhood (Porter and Thurman, 1963). The value of antimalarial chemoprophylaxis in malarial zones is established, but the value of prophylactic antibiotics in patients with and without a functioning spleen has yet to be investigated. Infection should be suspected in all patients presenting with sickle-cell crisis, but co-trimoxazole should be avoided for the treatment of infection in patients who are not taking folic acid supplements because of the risk of exacerbation of megaloblastic change (Lancet, 1973).

Infection is believed to precipitate crisis by inducing dehydration and local hypoxia. Certain infections, however, are associated with a raised plasma fibrinogen concentration (McGehee, Rapaport, and Hjort, 1967; Green, Kwaan, and Ruiz, 
1970) which may increase fibrinogen-red cell interaction (Replogle, Meiselman, and Merrill, 1967) and cause a rise in whole-blood viscosity. Our own patients in sickle-cell crisis have shown raised plasma fibrinogen levels (Gordon, Breeze, Mann, and Stuart, 1974) and this may contribute to impaired blood flow in those areas of the microvasculature with a low shear rate. Contrary to previous reports of decreased fibrinolytic activity in sickle-cell patients (Mahmood, Macintosh, and Shaper, 1967; Mahmood, 1969; Green et al, 1970; Walsh, Lusher, and Barnhart, 1973), our own studies have shown normal fibrinolytic activity during asymptomatic periods and in crisis (Gordon et al, 1974). It would appear, therefore, that fibrin once deposited is cleared at the normal rate.

The standard of supportive care for these patients is very important and folic acid supplements, antibiotics, antimalarial drugs, the avoidance of generalized or localized chilling, and the provision of home improvement grants and items such as electric blankets are factors likely to improve wellbeing and reduce the frequency and/or severity of vasoocclusive crises. It is important to remember that any clinical trial of prophylactic anti-sickling agents is itself likely to raise the standard of supportive care and therefore influence the result of the trial. The need for a control group is self evident but if multicentric trials are contemplated then a uniform standard of supportive care should also be adopted.

CLINICAL TRIALS OF PROPHYLACTIC AGENTS Individual patients show considerable variation in the number and severity of painful crises, and a cross-over trial, with the individual patient acting as his own control, is probably essential. This type of study is difficult to maintain over the minimum two-year period required to show an alteration in the frequency of crises. Patients with relatively few crises are very reluctant to continue with regular medication if it involves frequent and/or unpalatable doses. Patients who continue to have frequent crises will also question the value of the trial preparation after the first few months. Conversely, if there is an apparent dramatic response to one agent then the patient, or parents, may show a natural reluctance to 'cross over' at the half-way stage. We have found it particularly difficult to obtain continued informed consent for the whole duration of cross-over trials in our own immigrant patients.

These difficulties, together with the limitations set by the unpalatability and frequent dosage of oral bicarbonate and urea therapy, undoubtedly have an influence on the actual dosage taken by the patient. Cross-over trials have so far failed to show 2 that promazine $\mathrm{HCl}$ (Oski, Call, and Lessen, 1968) or bicarbonate (Mann and Stuart, 1974) can be given orally in a dosage which significantly reduces the frequency of crises. Oral urea therapy has failed to reduce the frequency of crises in one study (Lubin and Oski, 1973) and has achieved a reduction in another (Lusher and Barnhart, 1973), but neither of these trials contained a cross-over component and the results are therefore of limited value. Clinical trials of prophylactic cyanate therapy (Cerami and Manning, 1971; Gillette, Manning, and Cerami, 1971) have not yet been completed.

CLINICAL TRIALS IN THE ESTABLISHED CRISIS Many agents have been the subject of enthusiastic preliminary reports; none, so far, have been shown under double-blind trial conditions to be superior to rehydration, analgesics, and antibiotics in treating the vasoocclusive crisis (table II). Most of these agents have been used for their potential benefit in improving local vascular flow (dextran, warfarin, ancrod, and magnesium sulphate) or correcting local acidosis (bicarbonate and citrate). Only recently, with the introduction of urea (Nalbandian et al, 1971), cyanate (Cerami and Manning, 1971), carbamyl phosphate (Kraus and Kraus, 1971), and aspirin (Klotz and Tam, 1973) have agents been advocated for their potential effect at the molecular level.

\begin{tabular}{ll}
\hline Agent & Trial \\
\hline Sodium bicarbonate & $\begin{array}{l}\text { Schwartz and McElfresh (1964) } \\
\text { Dextran }\end{array}$ \\
Barnes, Hendrickse, and Watson-Williams \\
(1965) \\
Mann, Deeble, Breeze, and Stuart (1972) \\
Haddock, Konotey-Ahulu, Janosi, Ankra- \\
Badu, and Reid (1973) \\
Opio and Barnes (1972) \\
Cooperative Urea Trials Group \\
(1974)
\end{tabular}

Table II Double-blind clinical trials of agents used for treatment of established vasoocclusive crisis

The difficulties of clinical evaluation under strictly controlled trial conditions are common to all of these agents. There is difficulty in entering a patient into a trial when the suspected vasoocclusive crisis mimics an acute abdomen or osteomyelitis. Patients with an established infection, such as pneumonia, may also have to be excluded or randomized separately since persistent infection may prolong the crisis.

The duration of individual crises is extremely variable (hours to weeks) and this, together with the 
subjective nature of assessment of pain, makes it difficult to determine the end of a crisis. In these circumstances, the clinical assessment should be made by a 'blind' independent assessor who visits the patient for this purpose only. If a semi-quantitative clinical scoring technique is used in addition to assess pain, local swelling, and the effects of pressure or movement, then a much more objective assessment is obtained (Mann, Deeble, Breeze, and Stuart, 1972).

Sickle cells can undergo repeated cycles of sickling and unsickling before irreversible sickling occurs, but when a painful crisis has developed it must be assumed that irreversible sickling and tissue necrosis have developed. Anti-sickling agents may prevent additional red cells from sickling, but it is dubious whether they will have any effect on the 'irreversibly' sickled cell and they clearly cannot reverse tissue necrosis. Thus, in many crises, there is likely to be an obligatory painful period which may partially mask a beneficial effect of the agent under trial. The period of treatment and of clinical evaluation should therefore be long enough to allow for this and trials of three hours' duration (Opio and Barnes, 1972) would not seem to be adequate.

The duration of symptoms before commencing therapy should also be taken into account, and, ideally, the patient should be assessed hourly for the first few hours following admission in order to establish a baseline before specific anti-sickling therapy is initiated (Opio and Barnes, 1972).

The degree of sophistication required for the design of an ideal trial is therefore considerable. In the case of intravenous urea therapy, however, there are additional difficulties which limit clinical trial design. High-dose urea therapy requires supervision to intensive care unit standards with rapid fluid replacement to prevent dehydration. The dose of urea should be adjusted (Nalbandian, 1972) to maintain the blood urea nitrogen (BUN) between 150 and $300 \mathrm{mg} / 100 \mathrm{ml}$ (urea between 322 and $429 \mathrm{mg} / 100 \mathrm{ml}$ ), and hence fluid replacement, to compensate for the osmotic diuresis, varies from patient to patient. In addition, urea has a considerable sedative effect which may induce sleep (Nalbandian et al, 1971). It is clearly impossible to match these variables in control patients and therefore very difficult to distinguish the effects of urea from those of fluid exchange and sedation.

In this type of trial the emphasis should therefore be placed on selecting patients of an equivalent degree of severity for the control and urea treatment groups, on maintaining BUN levels within the recommended range for a defined period, and on measuring the response to therapy by an objective semi-quantitative technique. The aim, of course, is to determine not merely a statistically significant difference but whether high-dose urea therapy is so markedly superior to rehydration and analgesics that its use justifies the complexities and potential hazards of its administration. The results of the first double-blind trials of this type (Kraus, 1973; Cooperative Urea Trials Group, 1974) suggest that the rapid infusion of urea over a 24-hour period is not of clinical beneit. Blood urea nitrogen levels in excess of $150 \mathrm{mg} / 100 \mathrm{ml}$ were achieved in $74 \%$ of the patients although a lower $(15 \%)$ concentration of urea was used compared with the $30 \%$ concentration in the original Nalbandian et al (1971) protocol.

\section{Screening for Sickle-cell Disease}

When a screening programme for sickle-cell disease and other haemoglobinopathies is contemplated then a number of questions require to be answered: which is the most appropriate laboratory screening test for the population to be studied, which age group should be screened, what educational and genetic counselling facilities can be offered to individuals with an abnormal test result, and what is the cost and value of the whole programme?

It is easier to focus on these problems if the rather loose term 'screening' is more precisely defined in relation either to hospital patients and their families or community screening of individuals where there is no other contact with a hospital or health centre.

\section{HOSPITAL PATIENTS AND THEIR FAMILIES}

Every patient of African origin attending a hospital, or a dental or antenatal clinic, should be screened for sickle-cell haemoglobin since general anaesthesia may be required. Most laboratories now use a form of dithionite or solubility screening test (Itano and Pauling, 1949), followed by haemoglobin electrophoresis when a positive result is obtained. Hospital laboratories serving a population which comprises several racial groups, as in many areas of the United Kingdom, may perform a solubility test plus haemoglobin electrophoresis on all immigrant patients, or use other screening tests including blood film examination and a discriminant function derived from routine blood counts (England and Fraser, 1973). The number and selection of tests used should be based on the size and composition of the immigrant population.

It is vital, however, for a follow-up service to be provided for the patient when an abnormal test result is obtained. This service should include a 
detailed explanation of the significance of the abnormality, an offer to screen other family members and provide genetic counselling, and the provision of long-term follow up for homozygotes. A medical card, stating either a positive or a negative test result, should be issued to all family members. When the parents and several siblings have been tested it is important to check, before the cards are issued, that there is no overt genetic incompatibility which might subsequently raise questions as to paternity.

This type of service is time consuming and a haemoglobinopathy clinic, with facilities for children and adults, is therefore of value when a large number of patients is involved. The educational component of the service should also be extended to the medical and paramedical staff of the hospital and community (Stuart, Schwartz, Little, and Raine, 1973).

\section{COMMUNITY SCREENING}

In the United Kingdom, screening programmes for haemoglobinopathies are in their infancy but studies of selected patient groups have already illustrated the complexity of the problem (Modell, Benson, and Payling Wright, 1972; Stuart et al, 1973). In the United States, where there are more than 22 million black Americans (Neel, 1973), the problems are on a larger scale and additional difficulties have been created by the introduction of mandatory, rather than voluntary screening programmes. These have been strongly criticized (Culliton, 1972; Whitten, 1973) and at least one state (Massachusetts) has already substituted a voluntary programme (Robinson, 1973).

The size of the black population in the United States has stimulated the development of automated dithionite screening tests (Nalbandian, 1973a). Developments of this type, which allow 960-1200 specimens to be screened per eight-hour technician day, are more suited to intensive, short-term screening of selected communities such as schoolchildren and military recruits. This has allowed maximum advantage to be taken of educational programmes, including local television coverage (Nalbandian, 1973b), which are run simultaneously.

The educational component of these programmes is critically important in order to allay anxiety and to ensure a high percentage of attenders for primary screening and follow up. Education at the time of screening (Westring and Grand, 1973) would also seem to be important since the bulk of patients, with normal results, will not be recalled.

WHEN TO SCREEN

One of the major aims of community screening is to provide genetic counselling and it is not clear when this should be done and how effective it is likely to be. Married couples who are both carriers for a haemoglobinopathy are often willing to risk the $25 \%$ chance of a clinically affected child (Weatherall and Clegg, 1972). It is clear that there is a lack of acceptable alternatives to offer a married couple at this stage and screening should therefore be carried out earlier, and preferably at school age. For this reason, existing laws which require mandatory sickle screening before marriage in a few American states are likely to prove unacceptable.

Schoolchildren represent a large unified group where screening and genetic counselling are likely to be of significant value. The senior school years would seem to be the ideal time to do this (Bernstein, 1972) but others have found an apparent lack of interest at this age (Westring and Grand, 1973). While screening of younger children, with reinforcement on leaving school, may be of considerable benefit to the family as a whole, the educational component of screening programmes should be designed to stimulate concern in senior school students.

Screening in the newborn period is also of potential value to the family as a unit and may be linked with existing newborn screening programmes for phenylketonuria (Garrick, Dembure, and Guthrie, 1973). Screening of cord blood is feasible by a variety of techniques (Huntsman, Metters, and Yawson, 1972) and is of particular value when a high failure rate to attend follow-up paediatric clinics at three to six months of age is anticipated. There are, however, considerable technical advantages in delaying screening until 6 months of age when the foetal haemoglobin level has fallen, particularly when the thalassaemia gene is present in the community.

A number of well designed pilot studies are therefore required to determine the most appropriate time for screening, for education, and for genetic counselling in each individual population group.

IMPLICATIONS OF THE CARRIER STATE

As public awareness increases and as screening programmes become more sophisticated, the detection of the sickle-cell trait in an individual should no longer cause him anxiety and confusion. There still are, however, conflicting opinions regarding the clinical significance of the carrier state. It is recognized that fairly extreme physiological conditions may result in vaso-occlusive crises and fatalities have been reported (Jones, Binder, and Donowho, 1970). Many authors feel that the almost universally benign nature of the carrier state should be emphasized in order to reassure the 
individual and to obtain favourable life insurance and mortgage facilities. Others feel that the risks, however remote, should be stated for the protection of the individual (Mentzer, Lubin, and Nathan, 1970; Nalbandian, 1973b). These arguments are not mutually exclusive and life and medical insurance should be made available at normal premiums to the carrier, subject to a few provisos in relation to flying (Green, Huntsman, and Serjeant, 1971), performing athletics at altitude, and carrying a medical card stating the diagnosis.

\section{VALUE AND CONSEQUENCES OF SCREENING}

The overall value of community screening programmes is still a subject for debate and pilot studies are required to determine the problems in different communities. Mass screening should never be undertaken without preceding pilot studies. The design of these studies should be influenced by the population to be screened, by existing healthcare facilities and screening programmes, and by the financial implications of providing follow-up facilities. In poorer communities, particularly in paediatric practice, screening for anaemia may be of greater overall benefit, and should at least be incorporated in haemoglobinopathy screening programmes (Stuart et al, 1973).

If a mass screening programme is to be of value to, and accepted by, a community then emphasis must be placed on the educational aspect of the programme. This is of critical importance to obtain the informed support of the public; most of the criticisms directed against screening programmes are no longer valid when the individual is fully informed and asks to be screened.

\section{Conclusion}

The results of current clinical trials and community screening programmes in the United States are relevant to the management of sickle-cell disease in the United Kingdom. Irrespective of the longterm value of new anti-sickling agents which act at the molecular level, a great deal could be achieved by improving the standard of supportive care for these patients. Multicentric clinical studies should be established to investigate the incidence and the precipitating factors of the different types of crisis. These cooperative studies, which encompass obstetrical, paediatric, and adult medicine, should also be linked with therapeutic trials and with pilot studies of the value of community screening.

\section{References}

Barnes, P. M., Hendrickse, R. G., and Watson-Williams, E. J. (1965). Low-molecular-weight dextran in treatment of bonepain crises in sickle-cell disease: a double-blind trial. Lancet, 2, 1271-1273.
Bernstein, R. E. (1972). Detecting sickle haemoglobin. (Letter.) Brit. med. J., 4, 732.

Cerami, A., and Manning, J. M. (1971). Potassium cyanate as an inhibitor of the sickling of erythrocytes in vitro. Proc. nat. Acad. Sci. (Wash.), 68, 1180-1183.

Cooperative Urea Trials Group (1974). Treatment of sickle cell crisis with urea in invert sugar: a controlled trial. J. Amer. med. Ass., 228, 1125-1128.

Cotter, K. P., Walker, R. A., Bird, G. W. G., Mann, J. R., and Stuart, J. (1974). Exacerbation of anaemia in sickle-cell disease. In preparation.

Culliton, B. J. (1972). Sickle cell anemia: national program raises problems as well as hopes. Science, 178, 283-286.

Diggs, L. W. (1965). Sickle cell crises. Amer. J. clin Path., 44, 1-19.

Diggs, L. W., and Flowers, E. (1971). Sickle cell anemia in the home environment. Clin. Pediat. (Philad.)., 10, 697-700.

England, J. M., and Fraser, P. M. (1973). Differentiation of iron deficiency from thalassaemia trait by routine blood-count. Lancet, 1, 449-452.

Fort, A. T., Morrison, J. C., Berreras, L., Diggs, L. W., and Fish S. A. (1971). Counseling the patient with sickle cell disease about reproduction: pregnancy outcome does not justify the maternal risk. Amer. J. Obstet. Gynec., 111, 324-327.

Garrick, M. D., Dembure, P., and Guthrie, R. (1973). Sickle-cell anemia and other hemoglobinopathies. New Engl. J. Med. 288, 1265-1268.

Gillette, P. N., Manning, J. M., and Cerami, A. (1971). Increased survival of sickle-cell erythrocytes after treatment in vitro with sodium cyanate. Proc. nat. Acad. Sci. (Wash.)., 68, 2791-2793.

Gordon, P. A., Breeze, G. R., Mann, J. R., and Stuart, J. (1974), Coagulation-fibrinolysis in sickle-cell disease. J. clin. Path., 27, 485-489.

Green, D., Kwaan, H. C., and Ruiz, G. (1970). Impaired fibrinolysis in sickle cell disease. Thrombos. Diathes. haemorrh. (Stuttg.) 24, 10-16.

Green, R. L., Huntsman, R. G., and Serjeant, G. R. (1971). The sickle-cell and altitude. Brit. med. J., 4, 593-595.

Haddock, D. R. W., Konotey-Ahulu, F. I. D., Janosi, M., AnkraBadu, G., and Reid, H. A. (1973). Thrombosis in sickle-cel pain crises? Controlled trial of ancrod (Arvin) in young adults. J. trop. Med. Hyg., 76, 274-278.

Huntsman, R. G., Metters, J. S., and Yawson, G. I. (1972). The diagnosis of sickle cell disease in the newborn infant. J. Pediat. 80, 279-281.

Itano, H. A., and Pauling, L. (1949). A rapid diagnostic test for sickle cell anemia. Blood, 4, 66-68.

Jones, S. R., Binder, R. A., and Donowho, E. M., Jr. (1970). Sudden death in sickle-cell trait. New Engl. J. Med., 282, 323-325

Klotz, I. M., and Tam, J. W. O. (1973). Acetylation of sickle cell hemoglobin by aspirin. Proc. nat. Acad. Sci. (Wash.)., 70, 1313-1315.

Kraus, A. P. (1973). Clinical trials of therapy for sickle cell vasoocclusive crisis. (Abstr.). Clin. Res., 21, 872.

Kraus, L. M., and Kraus, A. P. (1971). Carbamyl phosphate mediated inhibition of the sickling of erythrocytes in vitro. Biochem. biophys. Res. Commun., 44, 1381-1387.

Lancet (1973). Co-trimoxazole and blood. Editorial. Lancet, 2, 950-951.

Lubin, B. H., and Oski, F. A. (1973). Oral urea therapy in children with sickle cell anemia. $J$. Pediat., 82, 311-313.

Lusher, J. M., and Barnhart, M. I. (1973). Oral prophylactic use of urea in sickle cell disease. Supp 1.Thrombos. Diathes. haemorrh. (Stuttg.), 53, 171-181.

McCurdy, P. R., and Mahmood, L. (1971). Intravenous urea treatment of the painful crisis of sickle-cell disease: a preliminary report. New Engl. J. Med., 285, 992-994.

McGehee, W. G., Rapaport, S. I., and Hjort, P. F. (1967). Intravascular coagulation in fulminant meningococcemia. Ann. intern. Med., 67, 250-260.

Mahmood, A. (1969). Fibrinolytic activity and sickle cell crises. Brit. med., J., 1, 52-53.

Mahmood, A., Macintosh, D. M., and Shaper, A. G. (1967). Fibrinolytic activity in the clinical crisis of sickle cell anaemia. Brit. med. J., 3, 653-654.

Mann, J. R., Deeble, T. J., Breeze, G. R., and Stuart, J. (1972). Ancrod in sickle-cell crisis. Lancet, 1, 934-937.

Mann, J. R., and Stuart J. (1974). Sodium bicarbonate prophylaxis of sickle cell crisis. Pediatrics, 53, 414-416. 
Mentzer, W. C., Jr., Lubin, B. H., and Nathan, D. G. (1970). Screening for sickle-cell trait and G-6-PD deficiency. New Engl. J. Med., 282, $1155-1156$.

Modell, C. B., Benson, A., and Payling Wright, C. R. (1972). Incidence of $\beta$-thalassaemia trait among Cypriots in London. Brit. med. J., 3, 737-738.

Nalbandian, R. M. (1972). Intravenous urea in management of sickle-cell crisis. (Letter.) Lancet, 2, 759.

Nalbandian, R. M. (1973a). Five new molecular-based tests for hemoglobin S. In Sickle Cell Hemoglobin: Molecule to Man, edited by M. Murayama and R. M. Nalbandian, pp. 67-102. Little, Brown, Boston.

Nalbandian, R. M. (1973b) Comprehensive automated mass screening programs for sickle cell disease. In Sickle Cell Hemoglobin: Molecule to Man, edited by M. Murayama and R. M. Nalbandian, pp. 103-129. Little, Brown, Boston.

Nalbandian, R. M., Shultz, G., Lusher, J. M., Anderson, J. W., and Henry, R. L. (1971). Sickle cell crisis terminated by intravenous urea in sugar solutions - a preliminary report. Amer. J. med. Sci., 261, 309-324.

Neel, J. V. (1973). Sickle cell disease: a worldwide problem. In Sickle Cell Disease: Diagnosis, Management, Education and Research, edited by H. Abramson, J. F. Bertles, and D. L. Wethers, pp. 4-12. Mosby, Louis.

Opio, E., and Barnes, P. M. (1972). Intravenous urea in treatment of bone-pain crises of sickle-cell disease: a double-blind trial. Lancet 2, 160-162.

Oski, F. Call, F. L. II, and Lessen, L. (1968). Failure of promazine
$\mathrm{HCl}$ to prevent the painful episodes in sickle cell anemia. J. Pediat., 73, 265-266.

Porter, F. S., and Thurman, W. G. (1963). Studies of sickle cell disease. Amer. J. Dis. Child., 106, 35-42.

Replogle, R. L., Meiselman, H. J., and Merrill, E. W. (1967). Clinical implications of blood rheology studies. Circulation, 36, 148-160.

Robinson, D. (1973). Sickle cell-point, counterpoint. New Engl. J. Med., 289, 323-324.

Rutkow, I. M., and Lipton, J. M. (1974). Some negative aspects of state health departments' policies related to screening for sickle cell anemia. Amer. J. publ. Hlth, 64, 217-221.

Schwartz, E., and McElfresh, A. E. (1964). Treatment of painful crises of sickle cell disease: a double blind study. J. Pediat., 64, 132-133.

Stuart, J., Schwartz, F. C. M., Little, A. J., and Raine, D. N. (1973). Screening for abnormal haemoglobins: a pilot study. Brit. med. J., 4, 284-287.

Walsh, R. T., Lusher, J. M., and Barnhart, M. I. (1973). Coagulation and fibrinolysis studies in sickle cell anemia. Thrombos, Diathes. haemorrh. (Stuttg.), Suppl. 53, 271-279.

Weatherall, D. J., and Clegg, J. B., Editors (1972). The Thalassaemia Syndromes, 2nd ed., p. 286. Blackwell, Oxford.

Westring, D. W., and Grand, S. (1973). Screening for sickle hemoglobin-a review. Amer. J. med. Sci., 265, 358-366.

Whitten, C. F. (1973). Sickle cell programming - an imperiled promise. New Engl. J. Med., 288, 318-319. 